College of Medicine, Prof. K. Yashika at the College of Biomedical Technology, and Dr. T. Ono at the Institute of Microbial Diseases, Osaka University. We also thank Prof. W.M. Flygare, at Kyoto University of Foreign Languages for revision of the English script.

\title{
RFFERFNCFS
}

1) Kadota, K. nvd Nagata, M.: Japam. J. Pharmacol. 25, 602 (1975); 2) Yonezawa, S.: Okavama Igakkai Zasshi 54, 691 AND 861 (1942) (in Japantese); 3) SzFrb, J.C.: J. Physiol. 158, 8P (1961); 4) WHITTAktR, V.P.: Preparation and use of subcellular fractions in newochemistry, Laboratory Note, Edited by WhitTaker, V.P.; 5) WhitTAker, V.P., Mich.Aelson, I.A. AND Kirklayd, R.J.A.: Biochem. J. 90, 293 (1964): 6) Forkester, T.: J. Physiol. 187, 12P (1966):

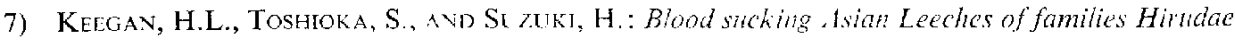
and Haemodipsidae, A contribution from the Dept. Entomology, 406th Medical Laboratory, p. 23 U.S. Army Medical Command, Japan (1968); 8) Fukumoto, T.: J. Chiba Mcd. Soc. 7, 127 (1939); 9) YOSHIDA, T. AND Yosilmura, M. : Folia pharmacol.japon. 51, 715 (1955) (in Japancse); 10) Furukawa, Y., Ikeda, M., and OHkubo, T.: Japan. J. Veterinary Sci. 25, 33 (1963): 11) Fuinf.r, H.: Biochem. Z,92,347(1918); 12) Fuh Avd 81 (1918); 13) Minz, B.: Arch exp. Path. Phamakol. 168, 292 (1932); 14) ChAv, H.C. And Gaddum, J.H.: J. Physiol. 79, 18 (1933); 15) Macintosch, F.C. ANd Plirr, W.1.M.: Meth. med. Res. 3, 78 (1950); 16) Schain, R.J.: Brit. J. Pharmacol. 16, 257 (1961); 17) Florex, E.: A. Rev. Physiol. 23, 501 (1961): 18) Hebr, C. AND Morris, D.: The Structure and Function of Nervous Tissue, Edited by Bourw, G.H., Vol. III, p. 25, Academic Press, Now York and London (1970); 19) Fletcher, P. And Forrester, T.: J. Physiol. 251, 131 (1975)

\section{BRADYKININ-INDUCED FLEXOR REFLEX OF RABBIT HINDLIMB FOR COMPARING ANALGESICS}

\author{
Takayuki DOI, Akinori AKAIKE, Masami OHASHI, \\ Masamichi SATOH and Hiroshi TAKAGI \\ Department of Pharmacology, Faculty of Pharmaceutical Sciences, \\ Kyoto University, Kyoto 606, Japan \\ Accepted June 7, 1976
}

Bradykinin, injected by the intra-arteriat or intra-peritoneal route, has been shown to induce painful sensation in man $(1,2)$ or nociceptive reactions in animal (3). Satoh et al. $(4,5)$ and Takagi et al. (6) reported that the bradykinin-induced unitary discharges of dorsal horn lamina $V$ cells in the spinal cord of the rabbit were inhibited by several analgesics including morphine and indomethacin. Although these electrophysiological studics are suitable for investigating the site and mode of actions of analgesics, much time and labor are required to examine a large number of analgesies. Blane (7) and Abe et al. (8) adopted the disappearance of the head rotation and forelimb flexion following the bradykinininjection into the carotid artery as the measure of analgesic effect. As the assessment of the results appeared to be rather subjective, we recorded the bradykinin-induced flexor reflex of the hindlimb on smoked paper and the recorded reflexes were used as a measure 
of the nociceptive reaction.

Albino rabbits of both sexes weighing $2.7-3.5 \mathrm{~kg}$ were anesthetized with ether and a polyethylene cannula $(0.9 \mathrm{~mm}$ in diameter) was inserted in a retrograde manner into the deep femoral artery on either side for the purposes of injecting bradykinin. The experiments were started at least $2 \mathrm{hr}$ after the termination of inhalation of ether. Five or ten micrograms of bradykinin dissolved in $0.1 \mathrm{ml}$ saline was injected within $1 \mathrm{sec}$ at intervals of $15 \mathrm{~min}$ through the cannula. The materials used were: indomethacin arginate ( $1 \%$ in saline), aspirin $(1.7 \%$ in $2 \%$ potassium citrate solution), aminopyrine ( $5 \%$ in saline), morphine hydrochloride ( $1 \%$ in saline) and pentazocine (1.5\%, Sankyo). All drugs were administered intravenously.

As illustrated in Fig. 1A, the rabbit was fixed in a supine position and the hindlimb ipsilateral to the cannulated side was linked to a kymographion through a tension gauge (available range of $2-4 \mathrm{~kg}$ ) buffing slight movements of the hindlimb. In such a position, the rabbit was usually at rest and the hindlimbs were maintained in spontaneously extending but not flexing position. When $5-10 \mu \mathrm{g}$ of bradykinin was repeatedly injected into the femoral artery at intervals of $15 \mathrm{~min}$, a flexor reflex of the ipsilateral hindlimb was invariably elicited in each trial and recorded on a smoked paper of the kymographion (Fig. 1), whereas other pseudo-affective reactions such as vocalization, hyperpnea and struggling the upper body were not consistently exhibited. The latencies of the ipsilateral hindlimb flexor reflex were 4-15 sec, corresponding to a fair degree with those of bradykinin-induced excitation of the lumbar dorsal horn lamina $V$ cells (4). Repeated injections of 1-2 $\mu \mathrm{g}$ of bradykinin at intervals of less than $10 \mathrm{~min}$ induced a tachyphylaxis in the flexor reflex. In rabbits in which the spinal cord was transected at $\mathrm{L}_{2}-\mathrm{L}_{3}$, the magnitude of the flexor reflex
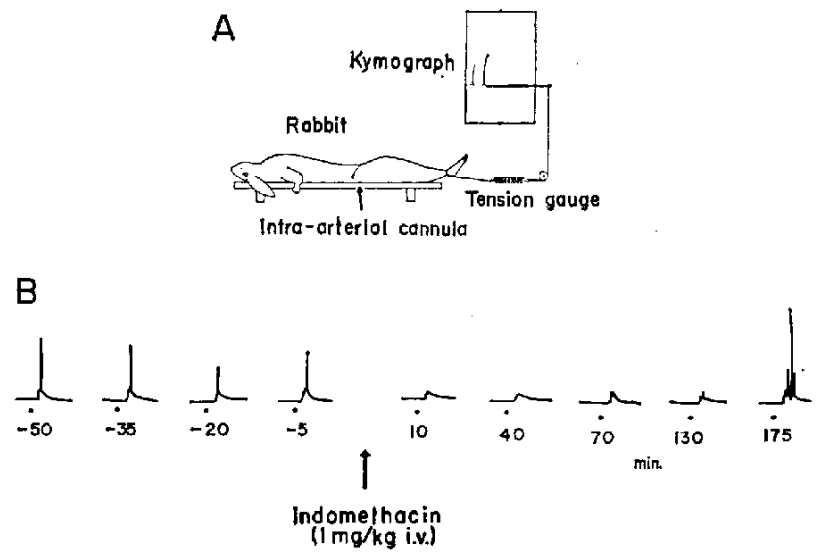

FIG. 1. A: Schematic illustration of the method. The rabbit was fixed in a supine position and the hindlimb ipsilateral to the bradykinin-injected side was linked to a kymographion through a tension gauge (available range of $2-4 \mathrm{~kg}$ ). The bradykinin-induced hindlimb flexor reflex was recorded on the kymographion, the smoked drum of which was rotated at a speed of $5 \mathrm{~mm} / \mathrm{min}$. B: Suppressive effect of indomethacin $(1.0 \mathrm{mg} / \mathrm{kg}$ i.v. $)$ on the bradykinin-induced hindlimb flexor reflex. -5 means 5 min before the administration of drug. In this case $5 \% \mathrm{~g}$ of bradykinin was injected every $15 \mathrm{~min}$. 
was considerably smaller than that in intact rabbits, indicating involvement of supraspinal structures in the bradykinin-induced flexor reflex. Since the magnitudes of the flexor reflexes after each bradykinin injection varied in the same rabbit, at least four control trials were performed before the administration of drugs. The effect of test drugs on the flexor reflex was regarded as being inhibitory when the magnitudes of the flexor reflexes following at least two successive bradykinin injections after an administration of the drug were less than $50 \%$ of the smallest control magnitude and recovered to the control level.

Indomethacin $(0.5$ and $1.0 \mathrm{mg} / \mathrm{kg}$ ), aspirin (10 and $20 \mathrm{mg} / \mathrm{kg}$ ) and aminopyrine (10 and $30 \mathrm{mg} / \mathrm{kg}$ ) inhibited the bradykinin-induced response in a dose-dependent manner. The inhibitory effect of these drugs occurred within $30 \mathrm{~min}$ after the administrations and lasted for $90-120 \mathrm{~min}$. Morphine $(4.0 \mathrm{mg} / \mathrm{kg})$ or pentazocine $(5.0 \mathrm{mg} / \mathrm{kg})$ also inhibited the bradykinin-induced flexor reflex in the majority of animals tested. These results are summarized in Table 1.

TABLF 1. Effects of various analgesics on bradykinin-induced flexor reflex

\begin{tabular}{cccc}
\hline Drugs & $\begin{array}{c}\text { Doses } \\
(\mathrm{mg} / \mathrm{kg}, \mathrm{i} . \mathrm{v})\end{array}$ & $\begin{array}{c}\text { Inhibition } \\
\text { (number of animals) }\end{array}$ & $\begin{array}{c}\text { No clcar cflect } \\
\text { Indomethacin }\end{array}$ \\
0.5 & 1.0 & 2 & 1 \\
& 10 & 4 & 2 \\
Aspirin & 20 & 4 & 1 \\
& 10 & 5 & 4 \\
Aminopyrine & 30 & 1 & 5 \\
\hline Morphine & 2.0 & 4 & 6 \\
\hline Pentazocine & 4.0 & 2 & 2 \\
\hline
\end{tabular}

It has been reported that indomethacin, aspirin and aminopyrine are analgesics acting mainly at peripheral levels $(5,9)$. On the other hand, morphine and pentazocine are classified as centrally acting analgesics. The present experiments using the rabbit showed that the bradykinin-induced flexor reflex was suppressed by both peripherally and centrally acting analgesics. It is noteworthy that this flexor reflex was relatively susceptible to the former as judged by doses which were efrective. These results correspond to those obtained when we measured depressive action of peripherally acting analgesics on the unit activitics of lamina $V$ cell of the spinal dorsal horn induced by intra-arterial injection of bradykinin (5). From these data, it is suggested that the method outlined herein allows for an objective judgement concerning antinociceptive action and may be utilized for evaluating the analgesic actions of drugs, in particular, peripherally acting analgesics.

\section{REFERENCES}

1) Burch, G.E. ANd de Pasqualf, N.P.: Circulation Res. 10, 105 (1962); 2) Lim, R.K.S., Miller, D.G., Guzman, F., Rodgers, D.W., Rogers, R.W., Wang, S.K., Chao, P.Y. a.nd Shih, 
T.Y.: Clin. Pharmacol. Ther. 8, 521 (1967); 3) Guzman, F., Braun, C. And Lim, R.K.S.: Archs int. Pharmacodyn. Thér. 136, 353 (1962); 4) Satoh, M., Nakamura, N. and Takagi, H.: Europ. J. Pharmacol. 16, 245 (1971); 5) Satoh, M., Dol, T., KaWasaki, K., Akaike, A. AND TAKAGI, H.: Japan. I. Pharmacol. 26, 309 (1976); 6) TAKaGI, H., SATOH, M., Dot, T., KaWASAKI, K. And Akaike, A.: Archs int. Pharmacodyn. Thér, 221, $96(1976)$; 7) Blane, G.F.: J. Pharm. Pharmacol. 19, 367 (1967); 8) ABE, T., KaneKo, T. AND TAKAGI, H.: Folia pharmacol japon. 67, 9 (1971) (in Japanese); 9) Lim, R.K.S., Guzman, F., Rodgers, D.W., Goto, K., Braun, C., Dickerson, G.D. And Engle, R.J.: Archs int. Pharmacodyn. Therr. 152, 25 (1964) 